\title{
IMPACT OF POTASSIUM AND MANGANESE ON THE QUANTITY AND QUALITY YIELDS OF SQUASH (CUCURBITA PEPO L.)
}

\author{
K. E. M. Nassar, Hayam A. EL-Shaboury and Amany E. ELSonbaty \\ Soils, Water and Environment Res. Inst, Agric. Res. Centre, Giza, Egypt
}

Received: Jan. 29, 2019

Accepted: Feb. 10, 2019

\begin{abstract}
Two field experiments were performed at a private farm on the town of EL - Serw, Al - Zarqa region, Domiate Governorate, Egypt (Latitude $31^{\circ} 12^{1} \mathrm{~N}$; Longitude $31^{\circ} 37^{\prime}$ E) during the spring seasons of 2017 and 2018 on March $1^{\text {st }}$ for the two seasons. The main targets of these experiments were to raise the productivity of squash fruits as well as improve its nutritive content and quality characteristics. Split plot design with three replicates was used where $K$ - treatments i.e $0,62.5$ and $125 \mathrm{Kg} \mathrm{K}_{2} \mathrm{O} \mathrm{fed}{ }^{-1}$ were allotted to the main plots however, sub plots were comprised of different foliar spraying treatments of Mn namely $0,0.3$ and $0.6 \mathrm{~g} \mathrm{~L}^{-1}$.
\end{abstract}

Data obtained revealed the following important topics :

1- $K$ - soil application and foliar spraying of Mn had synergistic impacts on squash vegetative growth characteristics, yield and yield components as well as nutritive content and quality characteristics of squash fruits, except crude fiber and total phenol. Differences between either $K$ levels or Mn ones for all abovementioned parameters were significant and treatments of $K_{2}$ and $M_{2}$ achieved the highest values.

2- Additional positive effects were observed when the addition of $K$ and $M n$ simultaneously. In this concern, the best values were recorded at the treatment of $\mathrm{K}_{2} \times \mathrm{Mn}_{2}$ for all the investigated parameters. In brief, the productivity of squash fruits as well as their nutritive content and quality characteristics can be improved through $\mathrm{K}$ - soil application and foliar spraying of Mn at levels of $125 \mathrm{~kg} \mathrm{~K}_{2} \mathrm{O} \mathrm{fed}{ }^{-1}$ and $0.6 \mathrm{~g}$ $M n L^{-1}$, respectively in a dual treatment.

Key words: Squash fruits \& straw - Vegetative growth characteristics - Potassium Manganese $-K \times$ Mn interaction.

\section{INTRODUCTION}

The cucurbitaceae family is among the most important plant families supplying humans with edible products, useful fibers and several medical purposes (Majeed and Mahmoud, 1988). Cucurbits include cucumber, melon, pumpkin, squash and gourd. Among the cucurbits, squash (Curcurbita pepo L.) is one of the most vegetable crops grown extensively in tropical and sub-tropical countries of Europe and Africa. According to Egyptian Ministry of Agriculture and Land Reclamation, the total production area of squash in 2016 was 73558 fed produced
551023 ton fruits but this area increased slowly in past few years.

Special attention should be paid to potassium $(K)$ when the fertilization of vegetables especially cucurbits, since $K$ is the macronutrient most extracted and absorbed in largest amounts by the majority of these crops (Araújo et al., 2012). The same trend occured with different cucurbits such as melon (Silva Júnior et al., 2006), pumpkin (Silva et al, 2013) and watermelon (Almeida et al., 2012 and Nogueria et al., 2014). Yet, K has the strongest impact on plant growth, development and metabolism 
besides it's significance for quality attributes that determine fruit marketability, firmness and visual appearance (Al-Moshileh et al. 2005 and Al-Moshileh et al., 2017).

Foliar spraying of micronutrients offers a method of their supplying to higher plants more efficiency than methods involving root application, since it uses low rate and the micronutrient does not contact directly the soil especially when soil conditions are not suitable for ions availability (Darwesh, 2011). Among the micronutrients, manganese (Mn) plays several physiological and biochemical roles i.e. chlorophyll formation, synthesis of proteins, carbohydrate metabolism and energy transfer. $\mathrm{Mn}$ also acts as an activitor for many different enzymatic reactions and takes part in photosynthesis. In other words, it activates decarboxylase and dehydrogenase and it is considered a constituent of photosystem II complex
(PSII-Protein), Superoxide dismutase (SOD) and phosphatase.

Therefore, the objectives of the current investigation were to improve the yield of squash towards better production and quality through studying the impact of different levels of K-soil application and foliar spraying of $\mathrm{Mn}$ as well as their combinations on squash growth and yield. Nutritive contents and quality of squash fruits were also taken into consideration.

\section{METERIALS AND METHODS}

Tow field experiments were performed at a private farm on the town of EI - Serw, Al - Zarqa region, Domiate Governorate, Egypt (Latitude $31^{\circ} 12^{\prime} \mathrm{N}$; longitude $31^{\circ}$ $\left.37^{\prime} \mathrm{E}\right)$ during the spring seasons of 2017 and 2018 from March $1^{\text {st }}$. Random samples of the studied soils were taken prior to planting from the surface area $(0$ - $30 \mathrm{~cm}$ ). Some physical and chemical characteristics of the soils under investigation were determined according to Page (1982) and Klute (1986) presented in Table 1 ( $a$ and $b$ ).

Table (1) : Mechanical and chemical characteristics of the experimental soils (surface layer, at the depth of $0-30 \mathrm{~cm}$ ) before planting for the two studied seasons :

a) Physical analysis:

\begin{tabular}{|c|c|c|c|c|c|c|c|}
\hline \multirow[b]{2}{*}{ Season } & \multirow{2}{*}{$\begin{array}{c}\mathrm{CaCO}_{3} \\
(\%)\end{array}$} & \multirow{2}{*}{$\begin{array}{l}\text { O.M } \\
(\%)\end{array}$} & \multicolumn{4}{|c|}{ Particle size distribution (\%) } & \multirow[b]{2}{*}{ Texture class } \\
\hline & & & $\begin{array}{c}\text { Coarse } \\
\text { sand }\end{array}$ & $\begin{array}{l}\text { fine } \\
\text { sand }\end{array}$ & Silt & Clay & \\
\hline $1 \underline{\text { st }}$ & 2.87 & 1.73 & 2.09 & 31.70 & 36.41 & 29.80 & Silt clay loam \\
\hline 2 nd & 2.68 & 1.68 & 2.16 & 31.74 & 38.15 & 27.95 & Silty clay loam \\
\hline
\end{tabular}

b) Chemical analysis :

\begin{tabular}{|c|c|c|c|c|c|c|c|c|}
\hline \multirow{3}{*}{ Season } & \multirow{3}{*}{$\begin{array}{l}\text { pH (1 : } 2.5) \\
\text { Soil : Water } \\
\text { suspension }\end{array}$} & \multirow{3}{*}{$\begin{array}{c}\mathrm{EC}_{\mathrm{e}}\left(\mathrm{dSm}^{-1}\right) \\
(1: 5) \mathrm{Soil}^{-1} \\
\text { Extract }\end{array}$} & \multicolumn{6}{|c|}{ Available nutrients (ppm) } \\
\hline & & & \multicolumn{3}{|c|}{ Macro } & \multicolumn{3}{|c|}{ Micro } \\
\hline & & & $\mathbf{N}$ & $\mathbf{P}$ & $\mathbf{K}$ & $\mathrm{Fe}$ & Mn & Zn \\
\hline 1 st & 8.05 & 0.97 & 53.8 & 4.66 & 187.5 & 3.17 & 1.48 & 0.64 \\
\hline 2 nd & 7.98 & 1.05 & 49.7 & 4.49 & 193.6 & 2.95 & 1.32 & 0.58 \\
\hline
\end{tabular}


Each experiment included nine treatments which were the combination of three levels of potassium soil application $\left(\mathrm{K}_{\mathrm{o}}=0.0, \mathrm{~K}_{1}=62.5 \mathrm{Kg} \mathrm{K} \mathrm{K}_{2} \mathrm{O}\right.$ fed $^{-1}$ and $K_{2}=125.0 \mathrm{Kg} \mathrm{K}_{2} \mathrm{O} \mathrm{fed}^{-1}$ ) and three rates of manganese foliar spraying $\left(\mathrm{Mn}_{\mathrm{o}}=0.0, \mathrm{Mn}_{1}=0.3 \mathrm{~g} \mathrm{Mn} \mathrm{L}^{-1}\right.$ and $\mathrm{Mn}_{2}=$ $0.6 \mathrm{~g} \mathrm{Mn} \mathrm{L}^{-1}$ ). Therefore, the experimental design was split plot design based on a randomized complete block design (RCBD) in three replications, where K treatments were allotted to the main plots however, sub plots were comprised of different foliar spraying treatments of $\mathrm{Mn}$. Each plot was comprised of three ridges $12 \mathrm{~m}$ length, $1 \mathrm{~m}$ width and $50 \mathrm{~cm}$ spacing between plants in row.

Organic manure was used at $20 \mathrm{~m}^{3}$ fed $^{-1}$, spread and thoroughly mixed with the soil surface layer $(0-30 \mathrm{~cm})$ before seed sowing during the soil preparation. Mineral fertilizers were added as the following: calcium superphosphate $\left(15.5 \% \mathrm{P}_{2} \mathrm{O}_{5}\right)$ was applied once during the soil preparation at a rate of $30 \mathrm{~kg} \mathrm{P}_{2} \mathrm{O}_{5}$ $\mathrm{fed}^{-1} . \mathrm{N}-$ fertilization was applied at $75 \mathrm{~kg}$ $\mathbf{N}$ fed $^{-1}$ in three portions i.e. 25,15 and 35 kg $\mathrm{N}$ fed $^{-1}$ at 21,35 and 50 days after sowing, respectively in the forms of ammonium sulphate $(20.6 \% \mathrm{~N})$ and urea $(46 \% \mathrm{~N})$ for the $1^{\text {st }}$ addition and ammonium nitrate $(33.5 \% \mathrm{~N})$ for the $2^{\text {nd }}$ and $3^{\text {rd }}$ additions. However, $\mathrm{K}$ treatments were soil applied in the form of potassium sulphate $\left(48 \% \quad \mathrm{~K}_{2} \mathrm{O}\right)$ at levels of $0,62.5$ and $125 \mathrm{~kg} \mathrm{~K}_{2} \mathrm{O} \mathrm{fed}^{-1}$, corresponding to 0 , half the recommended dose and the recommended dose, respectively. Treatments of $\mathrm{K}$ were applied directly in the planting rows at the same appointments of $\mathrm{N}$ - fertilization doses mentioned before. Besides, treatments of $\mathrm{Mn}\left(0,0.3\right.$ and $\left.0.6 \mathrm{~g} \mathrm{Mn} \mathrm{L}^{-1}\right)$ were foliar sprayed as Mn-EDTA form at 21, 35 and 50 days after sowing. Other agricultural practices were similarly performed as followed by farmers in the area.
Pure seeds of squash c.v (Rita squash $F_{1}$ Hybrid) were sown on $1^{\text {st }}$ March for the two seasons under investigation.

\section{Data recorded:}

1- Chlorophyll contents $a, b,(a+b)$ and carotene in the fresh recently expanded leaves (mg/g F.W) were determined calorimetrically as described by Sadasivam and Manickam, (1996).

2- Fruit yield was harvested at 45 days after sowing day after day intervals up to the end of the harvest time (23 harvests). For each harvest, it was measured average fruit length and diameter $(\mathrm{cm})$ per plot $\left(36 \mathrm{~m}^{2}\right)$ as well as total weight of fruits I plot all over the season, then calculated as total fruit yield (ton I fed). Dry weights of both fruits and straw were determined at mid harvesting season i.e. at $12^{\text {th }}$ harvest, where 100 grams of either fresh fruits or straw from different samples of each treatment were oven dried at $70^{\circ} \mathrm{C}$ until weight constancy.

3- Concentrations of $N, P$ and $K(\%)$ as well as $\mathrm{Fe}, \mathrm{Mn}$ and $\mathrm{Zn}$ (ppm) for leaves, at 60 days age as well as both fruits and straw at mid harvesting season were determined in wet digested extract used the methods described by Chapman and Pratt (1961). Then, macro - and micronutrients contents in both fruits and straw were also estimated as, $\mathrm{Kg}$ or g/fed, respectively.

4- The studied quality characteristics of fresh squash fruits were also estimated as follows : Crude protein percentage was determined by multiplying $N \%$ in fruits by 5.75 , according to A. O. A. C (2000). crude fiber percentage was also determined according to A. O. A. C (2000). Percentages of both total carbohydrates and sugars were 
determined according to Sadasivam and Manickam, (1996). Vitamin C (ascorbic acid) content was determined by titration with 2,6 dichlorophenol indophenal blue dye (Jacobs, 1951). Phenol content was determined according to Slinked and Singleton (1977).

5- In the end of the two investigated seasons, a random sample of five plants was taken from each plot for measuring some vegetative growth characteristics of squash plants i.e plant length $(\mathrm{cm})$ and number of leaves I plant.

6- For all recorded data, combined analyses of the two studied seasons were statistically analyzed according to Gomez and Gomez (1984). The least significant differences (L.S.D) test were used to compare the means of treatments at the $5 \%$ level of significance.

\section{RESULTS AND DISCUSSION}

The present study aimed to raise the productivity of squash fruits as well as improve its nutritive and biocontents. Hence, data attained herein included the influence of different levels of $\mathrm{K}$ - Soil application and foliar spraying of $\mathrm{Mn}$ and their possible combinations on photosynthetic pigments and nutrients contents of squash leaves as well as the yields of squash fruits, straw and their nutritive contents. Yet, impacts on some fruits biocharacteristics i.e. total protein, carbohydrates, sugar and crude fiber percentages as well as vitamin $C$ and total phenol contents were also taken into consideration.

I- Effect on photosynthetic pigments and nutrients contents of squash leaves:

Data recorded in Table (2) revealed that chlorophyll $a, b, a+b$ and carotene contents in squash leaves were significantly enhanced as the addition of $\mathrm{K}$ or $\mathrm{Mn}$. In this concern, the highest values for all abovementioned pigments were observed with the treatments of $K_{1}$ and $\mathrm{Mn}_{2}$. The addition of $\mathrm{K}$ and $\mathrm{Mn}$ together had a favorable impact on photosynthetic pigments and the application of $K_{1}$ and $M n_{2}$ gave the best values. Al- Moshileh et al. (2017) also observed that leaf chlorophyll content was correlated with $\mathrm{K}$ content and application of $250 \mathrm{ppm} \mathrm{K}$ gave the highest leaf $K$ - concentration and chlorophyll percentage. Hebbarb et al. (2004) and Al - Jaloud et al. (2006) also obtained trends similar to the previous one. On the other hand, Mn plays an important role in oxidation and reduction processes in plants such as the electron transport in photosynthesis. Mn also has an essential role in chlorophyll production in photosystem II (Marschner, 1995). Marco. and micronutrients contents in squash leaves gave also the same trends attained with photosynthetic pigments. In this connection, Al-Mukhtar et al. (1988) and Marie and Mohammed (2010) interpreted the promoting impact of $K$ to its physiological role in stimulating enzymes responsible for carbohydrate and protein synthesis as well as energy production. Also, $\mathrm{K}$ is considered the main carrier of $\mathrm{NO}_{3}^{-}$from the root through xylem to the leaves and activates reduction of $\mathrm{NO}_{3}^{-}$inside the plant to produce ammonia then to amino acids (Al-Sahaf, 1989) associated with each other to form proteins. Hence, the physiological and nutritional state of plant will improve.

On the other hand, the promoting effect of Mn may be due to its important role in chlorophyll production, activator for more than 35 different enzymes include the nitrate reducing enzyme and those responsible for carbohydrates and lipids metabolism and enzymes of dehydrogenase and decarboxylase in the kerbs cycle (TCA) (Burnell, 1988 and Marschner, 1995). $\mathrm{Mn}^{2+}$ in terms of biochemical function is similar to $\mathbf{M g}^{2+}$. 
Both ions connect ATP with complexes enzymes (phosphotransferase and phosphokinase). Thus, under Mn deficiency, protein, carbohydrate and lipids declined and plant growth reduced (Anderson and pyliotis, 1996 and Marschner, 1995).

In addition, Orhue and Nwaoguala (2010) on pumpkin found that application of $\mathrm{Mn}$ up to $20 \mathrm{Kg} \mathrm{ha} \mathrm{ha}^{-1}$ increased significantly the growth parameters and shoot dry weight. They also stated that as $\mathrm{Mn}$ levels increased, $\mathrm{N}, \mathrm{P}, \mathrm{K}, \mathrm{Ca}, \mathrm{Mg}$, $\mathrm{Mn}, \mathrm{Zn}$ and $\mathrm{Cu}$ contents of the plants increased consistently with significant differences recorded among the various Mn levels.

Table (2): Photosynthetic pigments and nutrients concentrations in squash leaves as affected by $\mathrm{K}$ - soil application and foliar spraying of $\mathrm{Mn}$ as well as their combinations*.

\begin{tabular}{|c|c|c|c|c|c|c|c|c|c|c|c|}
\hline \multirow{3}{*}{\multicolumn{2}{|c|}{ Treatments }} & \multicolumn{4}{|c|}{$\begin{array}{l}\text { Photosynthetic pigments } \\
\text { (mg / g F. W) }\end{array}$} & \multicolumn{6}{|c|}{ Leaves nutrients concentrations } \\
\hline & & \multirow{2}{*}{ Chl (a) } & \multirow{2}{*}{ Chl (b) } & \multirow{2}{*}{ Chl $(a+b)$} & \multirow{2}{*}{ Carotene } & \multicolumn{3}{|c|}{$\%$} & \multicolumn{3}{|c|}{ ppm } \\
\hline & & & & & & $\mathbf{N}$ & $\mathbf{P}$ & $\mathbf{K}$ & $\mathrm{Fe}$ & Mn & $\mathrm{Zn}$ \\
\hline \multicolumn{12}{|c|}{$\mathrm{K}$ - soil application levels ( $\mathrm{Kg} \mathrm{K}_{2} \mathrm{O}$ fed $^{-1}$ ) } \\
\hline \multicolumn{2}{|c|}{$\mathrm{K}_{\mathrm{o}}$} & 0.651 & 0.462 & 1.113 & 0.907 & 1.19 & 0.175 & 1.31 & 28.22 & 10.77 & 13.68 \\
\hline \multicolumn{2}{|c|}{$\mathbf{K}_{1}$} & 0.678 & 0.484 & 1.162 & 0.942 & 1.42 & 0.199 & 1.72 & 28.99 & 11.52 & 14.15 \\
\hline \multicolumn{2}{|c|}{$\mathrm{K}_{2}$} & 0.665 & 0.471 & 1.136 & 0.920 & 1.32 & 0.184 & 1.94 & 29.20 & 11.86 & 14.33 \\
\hline \multicolumn{2}{|c|}{ L. S. $D_{0.05}$} & 0.005 & 0.004 & 0.005 & 0.004 & 0.06 & 0.005 & 0.11 & 0.13 & 0.15 & 0.06 \\
\hline \multicolumn{12}{|c|}{ Mn - foliar spraying levels (g Mn $\left.L^{-1}\right)$} \\
\hline \multicolumn{2}{|c|}{$\mathrm{Mn}_{\mathbf{0}}$} & 0.625 & 0.443 & 1.069 & 0.868 & 0.98 & 0.149 & 1.44 & 28.24 & 10.31 & 13.69 \\
\hline \multicolumn{2}{|c|}{$\mathbf{M n}_{1}$} & 0.664 & 0.472 & 1.135 & 0.923 & 1.32 & 0.188 & 1.71 & 28.81 & 11.61 & 14.04 \\
\hline \multicolumn{2}{|c|}{$\mathrm{Mn}_{2}$} & 0.705 & 0.502 & 1.206 & 0.978 & 1.64 & 0.222 & 1.82 & 29.36 & 12.23 & 14.43 \\
\hline \multicolumn{2}{|c|}{ L. S. $D_{0.05}$} & 0.004 & 0.004 & 0.005 & 0.007 & 0.06 & 0.006 & 0.07 & 0.11 & 0.14 & 0.09 \\
\hline \multicolumn{12}{|c|}{$\mathrm{K} \times \mathrm{Mn}$ interactions } \\
\hline \multirow{3}{*}{$\mathbf{K}_{\mathbf{o}}$} & $\mathrm{Mn}_{\mathrm{o}}$ & 0.613 & 0.432 & 1.045 & 0.851 & 0.86 & 0.140 & 1.19 & 27.86 & 10.03 & 13.44 \\
\hline & $\mathrm{Mn}_{1}$ & 0.651 & 0.463 & 1.114 & 0.904 & 1.19 & 0.175 & 1.32 & 28.05 & 10.97 & 13.56 \\
\hline & $\mathrm{Mn}_{2}$ & 0.689 & 0.492 & 1.181 & 0.967 & 1.53 & 0.211 & 1.41 & 28.76 & 11.32 & 14.03 \\
\hline \multirow{3}{*}{$\mathbf{K}_{1}$} & $\mathrm{Mn}_{\mathrm{o}}$ & 0.639 & 0.455 & 1.094 & 0.889 & 1.08 & 0.163 & 1.50 & 28.31 & 10.30 & 13.72 \\
\hline & $\mathrm{Mn}_{1}$ & 0.674 & 0.483 & 1.158 & 0.947 & 1.42 & 0.199 & 1.76 & 29.06 & 11.73 & 14.19 \\
\hline & $\mathrm{Mn}_{2}$ & 0.720 & 0.512 & 1.233 & 0.991 & 1.75 & 0.235 & 1.88 & 29.59 & 12.51 & 14.55 \\
\hline \multirow{3}{*}{$\mathrm{K}_{2}$} & $\mathrm{Mn}_{\mathrm{o}}$ & 0.624 & 0.443 & 1.067 & 0.863 & 0.99 & 0.145 & 1.63 & 28.54 & 10.59 & 13.91 \\
\hline & $\mathrm{Mn}_{1}$ & 0.666 & 0.469 & 1.134 & 0.918 & 1.34 & 0.190 & 2.03 & 29.32 & 12.14 & 14.37 \\
\hline & $\mathrm{Mn}_{2}$ & 0.705 & 0.501 & 1.206 & 0.978 & 1.64 & 0.219 & 2.17 & 29.74 & 12.86 & 14.71 \\
\hline \multicolumn{2}{|c|}{ L. S. $D_{0.05}$} & 0.006 & 0.007 & 0.008 & 0.011 & 0.11 & 0.011 & 0.12 & 0.19 & 0.25 & 0.15 \\
\hline
\end{tabular}

*Combined analysis of the two studied seasons .

$\mathrm{K}_{\mathrm{o}}=0, \mathrm{~K}_{1}=62.5 \mathrm{Kg} \mathrm{K}_{2} \mathrm{O} \mathrm{fed}^{-1}, \mathrm{~K}_{2}=125 \mathrm{Kg} \mathrm{K}_{2} \mathrm{O} \mathrm{fed}^{-1}, \mathrm{Mn}_{\mathrm{o}}=0, \mathrm{Mn}_{1}=0.3 \mathrm{~g} \mathrm{Mn} \mathrm{L}^{-1}, \mathrm{Mn}_{2}=0.6 \mathrm{~g} \mathrm{Mn} \mathrm{L}^{-1}$. 
II- Effect on some vegetative growth characteristics as well as yield and yield parameters of squash:

Data presented in Table (3) show that plant lenght $(\mathrm{cm})$ and number of leaves $I$ plant, as two characteristics of vegetative growth, were gradually enhanced by the addition of either potassium or manganese. $\mathrm{K}_{2}$ and $\mathrm{Mn}_{2}$ treatments gave the best values. Data presented also showed that the addition of $\mathrm{K}$ and $\mathrm{Mn}$ simultaneously had a favorable impact on the tow characteristics mentioned before and the highest values were observed when the addition of $K_{2}$ and $\mathrm{Mn}_{2}$ together.

Table (3) : Some Vegetative growth characteristics, fruits and straw yields as well as some yield components as affected by $\mathrm{K}$ soil application foliar spraying of Mn and their combinations*.

\begin{tabular}{|c|c|c|c|c|c|c|c|c|c|}
\hline \multirow{2}{*}{\multicolumn{2}{|c|}{ Treatments }} & \multirow{2}{*}{$\begin{array}{l}\text { Plant } \\
\text { length } \\
\text { (cm) }\end{array}$} & \multirow{2}{*}{$\begin{array}{c}\text { Leaves } \\
\text { No.I } \\
\text { Plant }\end{array}$} & \multicolumn{3}{|c|}{ Fruit yield components } & \multicolumn{2}{|c|}{$\begin{array}{l}\text { Fruit yield } \\
\text { (ton fed }^{-1} \text { ) }\end{array}$} & \multirow{2}{*}{$\begin{array}{c}\begin{array}{c}\text { Straw yield } \\
\text { (ton fed }^{-1} \text { ) }\end{array} \\
\text { Dry }\end{array}$} \\
\hline & & & & $\begin{array}{l}\text { Fruit } \\
\text { length } \\
\text { (cm) }\end{array}$ & $\begin{array}{l}\text { Fruit } \\
\text { diameter } \\
(\mathbf{c m})\end{array}$ & $\begin{array}{c}\text { Fruit } \\
\text { Weight } \\
\text { (kg/plant) }\end{array}$ & Fresh & Dry & \\
\hline \multicolumn{10}{|c|}{$\mathrm{K}$ - soil application levels $\left(\mathrm{Kg} \mathrm{K}_{2} \mathrm{O} \mathrm{fed}^{-1}\right)$} \\
\hline \multicolumn{2}{|c|}{$\mathbf{K}_{\mathrm{o}}$} & 123.9 & 44.89 & 13.04 & 3.08 & 2.51 & 19.96 & 1.16 & 2.46 \\
\hline \multicolumn{2}{|c|}{$\mathrm{K}_{1}$} & 143.1 & 55.56 & 13.66 & 3.39 & 2.80 & 22.40 & 1.37 & 2.73 \\
\hline \multicolumn{2}{|c|}{$\mathrm{K}_{2}$} & 151.2 & 60.22 & 13.83 & 3.48 & 2.95 & 23.57 & 1.48 & 2.81 \\
\hline \multicolumn{2}{|c|}{ L. S. $D_{0.05}$} & 1.17 & 1.15 & 0.21 & 0.23 & 0.01 & 0.20 & 0.01 & 0.04 \\
\hline \multicolumn{10}{|c|}{ Mn foliar spraying levels (g Mn $\mathrm{L}^{-1}$ ) } \\
\hline \multicolumn{2}{|c|}{$\mathrm{Mn}_{\mathbf{o}}$} & 123.4 & 44.56 & 13.02 & 3.06 & 2.49 & 19.80 & 1.15 & 2.45 \\
\hline \multicolumn{2}{|c|}{$\mathrm{Mn}_{1}$} & 137.1 & 53.56 & 13.47 & 3.31 & 2.73 & 21.84 & 1.32 & 2.67 \\
\hline \multicolumn{2}{|c|}{$\mathrm{Mn}_{2}$} & 157.8 & 62.56 & 14.04 & 3.58 & 3.04 & 24.29 & 1.55 & 2.94 \\
\hline \multicolumn{2}{|c|}{ L. S. $D_{0.05}$} & 1.07 & 1.11 & 0.05 & 0.08 & 0.01 & 0.19 & 0.01 & 0.02 \\
\hline \multicolumn{10}{|c|}{$\mathrm{K} \times \mathrm{Mn}$ interactions } \\
\hline \multirow{3}{*}{$\mathrm{K}_{\mathrm{o}}$} & $\mathrm{Mn}_{\mathrm{o}}$ & 114.9 & 40.67 & 12.67 & 2.90 & 2.36 & 18.64 & 1.07 & 2.36 \\
\hline & $\mathrm{Mn}_{1}$ & 119.0 & 42.33 & 12.90 & 3.00 & 2.42 & 19.34 & 1.11 & 2.40 \\
\hline & $\mathrm{Mn}_{2}$ & 137.8 & 51.67 & 13.57 & 3.33 & 2.74 & 21.91 & 1.31 & 2.63 \\
\hline \multirow{3}{*}{$\mathbf{K}_{1}$} & $\mathrm{Mn}_{\mathrm{o}}$ & 125.2 & 44.67 & 13.10 & 3.07 & 2.49 & 19.90 & 1.16 & 2.46 \\
\hline & $\mathrm{Mn}_{1}$ & 142.1 & 56.00 & 13.70 & 3.40 & 2.81 & 22.49 & 1.38 & 2.74 \\
\hline & $\mathrm{Mn}_{2}$ & 162.1 & 66.00 & 14.17 & 3.70 & 3.10 & 24.80 & 1.59 & 3.00 \\
\hline \multirow{3}{*}{$\mathrm{K}_{2}$} & $\mathrm{Mn}_{\mathbf{0}}$ & 130.1 & 48.33 & 13.30 & 3.20 & 2.61 & 20.85 & 1.23 & 2.52 \\
\hline & $\mathrm{Mn}_{1}$ & 150.3 & 62.33 & 13.80 & 3.53 & 2.96 & 23.69 & 1.48 & 2.86 \\
\hline & $\mathrm{Mn}_{2}$ & 173.2 & 70.00 & 14.40 & 3.70 & 3.27 & 26.16 & 1.74 & 3.19 \\
\hline \multicolumn{2}{|c|}{ L. S. $D_{0.05}$} & 1.86 & 1.92 & 0.09 & 0.13 & 0.03 & 0.35 & 0.02 & 0.04 \\
\hline
\end{tabular}

*Combined analysis of the two studied seasons .

$\mathrm{K}_{\mathrm{o}}=0, \mathrm{~K}_{1}=62.5 \mathrm{Kg} \mathrm{K}_{2} \mathrm{O} \mathrm{fed}{ }^{-1}, \mathrm{~K}_{2}=125 \mathrm{Kg} \mathrm{K}_{2} \mathrm{O} \mathrm{fed}{ }^{-1}, \mathrm{Mn}_{\mathrm{o}}=0, \mathrm{Mn}_{1}=0.3 \mathrm{~g} \mathrm{Mn} \mathrm{L}^{-1}, \mathrm{Mn}_{2}=0.6 \mathrm{~g} \mathrm{Mn} \mathrm{L}^{-1}$. 
Data shown in Table (3) also revealed that both fresh and dry weights of squash fruits and fruits yield components studied herein namely fruit weight (Kg / plant) as well as length and diameter $(\mathrm{cm})$ were all significantly affected by the addition of either $\mathrm{K}$ or $\mathrm{Mn}$ at different levels. The maximum values for both squash fruit yield and its components were occurred. When the addition of $\mathrm{K} 2$ or $I$ and $\mathrm{Mn}_{2}$. K soil application simultaneously with foliar spraying of $\mathrm{Mn}$ had additional positive impacts on all above - mentioned parameters. Straw yield also took a trend similar to the previous one.

Enhancing of squash fruit yield as the addition of $\mathrm{K}$ might be interpreted on the basis of the critical demand of plant physiological activation for $\mathrm{K}$ during flowering and fruit setting stages. So, the soil application of $K$ result in increasing the amount of available $K$ in soil which accompanied with achieving the biological operations favorably which help in increasing number of fruits, average fruit weight and total yield (Marie and Mohammed, 2010). Fernandes et al. (2016) also reported that $K$ significantly influenced fruit diameter, pulp thickness, fruit mass and yield the zucchini crop. Moreover, Silva Júnior et al. (2006) on melon, (Araújo at al. (2012) on squash, Nogueira et al. (2014) on water melon, Silva et al. (2013) on pumpkin and Fernandes et al. (2016) on Zucchini recorded linear models for yield in response to $\mathrm{K}$ doses. They attributed that to the large demand of vegetable crops for $K$ which is the macronutrient most extracted by the majority of these plants. While, Grangeiro and Cecilio Filho (2006) observed that the yield of seedless watermelon showed a quadratic behaviour in response to $K$ doses. The lowest yield attained with the least dose of $K$ can be explained on the basis on its importance in the plants, being vital for photosynthesis. So, $\mathrm{K}$ deficiency cause a reduction in the photosynthetic rate and an increase in respiration, leading to decrease in the accumulation of carbohydrates (Novais et al., 2007). Another important effect of $K$ in the plant is related to the permeability of plant cell membranes and stomatal opening $I$ closure, so that, when there is a lack of $K$ in the plant, the stomata do not open regularly, which causes smaller entry of carbon dioxide and, therefore, lower photosynthetic intensity, result in yield reduction (Taiz and Zieger, 2009).

In addition, the positive effect of Mn on squash yield and its parameters was interpreted by Marschner (1995) who pointed out that $\mathrm{Mn}$ is considered an essential element required by all plant species for growth and reproduction. Inside the plant, $\mathrm{Mn}$ is a component of the water splitting protein complex, photosystem II complex (PSII); a constituent of superoxide dismutase (Mn SOD); an activator of a number of critical metabolic enzymes. Hence, Mn plays on important role in nitrogen metabolism by activating anginas and glut amyl transferase enzymes (Burnell, 1988). Mn is also required for the activation of Nicotinamide dinucleotide (NAD)-malic enzyme, a critical enzyme in the $\mathrm{C}-4$ photo synthetic pathway. Since, $M n$ is a constituent of the PSII in all plants, Its deficiency could significantly affect leaf photosynthetic activity, dry matter accumulation and yield of all plants.

\section{III- Effect on the contents of both macro- and micronutrients in squash fruits and straw: \\ Data shown in Table (4) revealed that the contents of both macro-and micronutrients in squash fruits and straw were progressively raised as increasing the levels of $K$ soil application, up to 125 $\mathrm{Kg} \mathrm{fed}^{-1}$ and $\mathrm{Mn}$ up to $0.6 \mathrm{~g} \mathrm{~L}^{-1}\left(\mathrm{~K}_{2}+\mathrm{Mn}_{2}\right)$. The statistical analysis of the obtained}




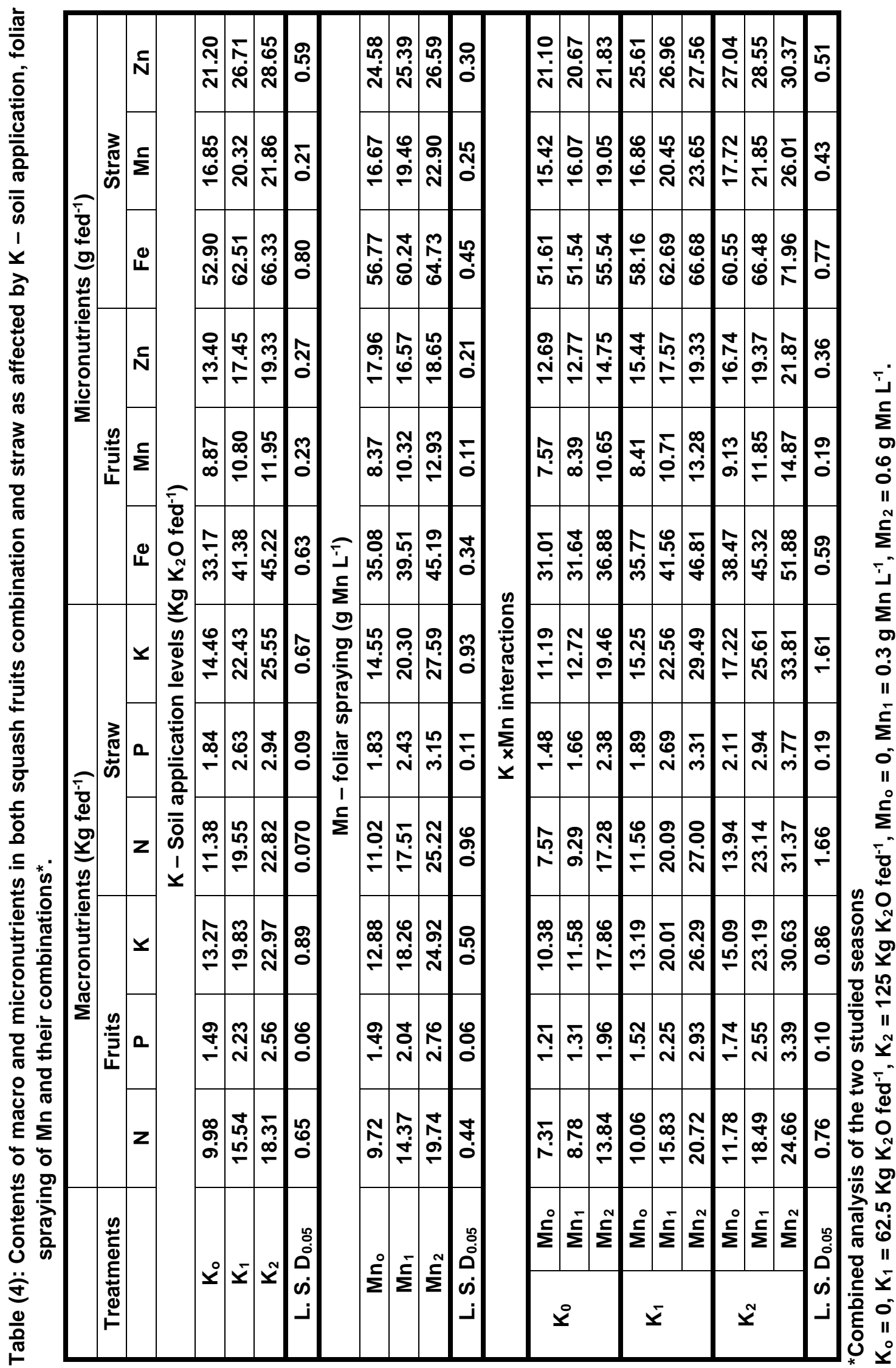


results showed that the differences within the levels of $\mathrm{K}$ on $\mathrm{Mn}$ addition were great enough to reach the $5 \%$ level of significance for all macro - and micronutrients in both squash fruits and straw. These results are in harmony with those obtained by Kacha et al. (2017) who stated that potash fertilization increased nutrients supply in rhizosphere which culminated into more absorption of nutrients by watermelon. Mohamed et al. (2010) also observed that nutritional contents of fruits (N, P, K, Fe, Mn, Zn and $\mathrm{Cu})$ recorded their highest values when plants were sprayed by $\mathrm{N}+\mathrm{K}$. In addition, Orhue and Nwaoguala (2010) stated that as $\mathrm{Mn}$ levels increased, $\mathrm{N}, \mathrm{P}, \mathrm{K}, \mathrm{Ca}, \mathrm{Mg}$, $\mathrm{Mn}, \mathrm{Zn}$ and $\mathrm{Cu}$ contents of the plants increased consistently with significant differences were recorded among the various Mn levels.

\section{IV- Effect on some quality characteristics of squash fruits :}

Data in Table (5) showed clearly that as $\mathrm{K}$ on Mn levels increased, percentages of total protein, carbohydrate and sugar as well as vitamin C content $(\mathrm{mg} / \mathbf{1 0 0 \mathrm { g }})$ of squash fruits increased consistently with significant differences were recorded among either the various $K$ or $\mathrm{Mn}$ levels. In this concern, the highest values for all abovementioned characteristics were observed with the treatments of $\mathrm{K}_{2}$ or I and $\mathrm{Mn}_{2}$. Additional positive impacts were also noticed when $\mathrm{K}$ and $\mathrm{Mn}$ were added simultaneously and maximum values were attained at the treatment of $\mathrm{K}_{2} \times \mathrm{Mn}_{2}$. These results are similar to those obtained by Prajapati and Modi (2012) who reported that K plays significant roles in improving all characteristics related quality and the feeding value of many crops. $K$ also activates the enzymes responsible for synthesis of protein and starch and it is required for every major step of protein synthesis. The "reading" of the genetic code in plant cells to produce proteins and enzymes that regulate all growth processes would be impossible act without adequate $\mathrm{K}$. Potassium also balances negatively amino acids like aspartate and glutamate and stabilizes protein - water layer interactions (Marschner, 1995). Prajapati and Modi (2012) also revealed that sugar produced in photosynthesis must be transported through the phloem to other parts of the plant for utilization and storage. This system uses energy in the form of ATP. If $K$ is inadequate, less ATP is available and the transport system breaks down. Moreover, the enzyme responsible for synthesis of starch (starch syntheses) is activated by $K$. thus, with inadequate $K$, the level of starch declines while, soluble carbohydrates and N - compounds accumulate (Patil, 2011, Prajapati and Modi, 2012). Potassium deficiency can also cause reduced yield potential and quality long before visible - symptoms appear. This "hidden hunger" robs profits from the farmer who fails to keep soil $K$ levels in the range high enough to supply adequate $K$ at all times during the growing season. Besides, inside the plant, $\mathrm{Mn}$ is a component of the water splitting protein complex (PSII) a constituent of superoxide dismutase (Mn SOD) and a key activator of number of critical metalic enzymes (Marschner, 1995). Mn also plays a role in nitrogen metabolism by activating arginas and glutamyl transferase enzymes (Burnell, 1988). $\mathrm{Mn}$ is also required for the activation of NAD - malic enzyme, a critical enzyme in the $C-4$ photosynthetic pathway. On the contrary, crude fiber percentage and total phenol content (mg $I \mathrm{100 \textrm {g }}$ ) of the plant decreased consistently with increasing $K$ or Mn levels. 
Declination of crude fiber percentage and total phenol content as increasing the tested levels of $K$ and $M n$ was previously observed by many investigators. In this connection, Prajapati and Modi (2012) reported that with inadequate $\mathrm{K}$, soluble carbohydrates accumulate and crude fiber is considered one of different constituents of soluble carbohydrates. Oloyede et al. (2012) noticed the reduction in total phenolics and antioxidant activities in Mustard leaf due to increase NPK fertilization.

Table (5) : Effect of $\mathrm{K}$ - Soil application, foliar spraying of $\mathrm{Mn}$ and their combinations on some quality characteristics of squash fruits*.

\begin{tabular}{|c|c|c|c|c|c|c|c|}
\hline \multirow{2}{*}{\multicolumn{2}{|c|}{ Treatments }} & \multicolumn{4}{|c|}{$\%$} & \multicolumn{2}{|c|}{$\mathrm{mg} / 100 \mathrm{~g} \mathrm{F.} \mathrm{W}$} \\
\hline & & $\begin{array}{l}\text { Total } \\
\text { protein }\end{array}$ & $\begin{array}{c}\text { Total } \\
\text { carbohydrates }\end{array}$ & $\begin{array}{l}\text { Total } \\
\text { sugar }\end{array}$ & $\begin{array}{l}\text { Crude } \\
\text { fiber }\end{array}$ & V. C & $\begin{array}{c}\text { Total } \\
\text { phenol }\end{array}$ \\
\hline \multicolumn{8}{|c|}{$\mathrm{K}$ - soil application levels $\left(\mathrm{Kg} \mathrm{K}_{2} \mathrm{O}\right.$ fed $\left.^{-1}\right)$} \\
\hline \multicolumn{2}{|c|}{$\mathbf{K}_{\mathbf{o}}$} & 4.87 & 16.86 & 3.47 & 5.50 & 20.20 & 249.91 \\
\hline \multicolumn{2}{|c|}{$\mathrm{K}_{1}$} & 6.37 & 17.83 & 4.20 & 4.84 & 21.86 & 234.19 \\
\hline \multicolumn{2}{|c|}{$\mathbf{K}_{2}$} & 6.96 & 18.15 & 4.45 & 4.61 & 22.24 & 229.04 \\
\hline \multicolumn{2}{|c|}{ L. S. $D_{0.05}$} & 0.26 & 0.12 & 0.14 & 0.13 & 0.67 & 1.17 \\
\hline \multicolumn{8}{|c|}{ Mn foliar spraying levels (g Mn L-1) } \\
\hline \multicolumn{2}{|c|}{$\mathbf{M n}_{\mathbf{0}}$} & 4.82 & 16.86 & 3.46 & 5.50 & 20.09 & 249.84 \\
\hline \multicolumn{2}{|c|}{$\mathrm{Mn}_{1}$} & 6.13 & 17.62 & 4.04 & 4.99 & 21.49 & 238.06 \\
\hline \multicolumn{2}{|c|}{$\mathrm{Mn}_{2}$} & 7.25 & 18.36 & 4.62 & 4.45 & 22.72 & 225.24 \\
\hline \multicolumn{2}{|c|}{ L. S. $D_{0.05}$} & 0.20 & 0.08 & 0.11 & 0.08 & 0.40 & 2.33 \\
\hline \multicolumn{8}{|c|}{$\mathrm{K} \times \mathrm{Mn}$ interactions } \\
\hline \multirow{3}{*}{$\mathrm{K}_{0}$} & $\mathrm{Mn}_{\mathbf{0}}$ & 3.93 & 16.33 & 3.06 & 5.87 & 19.23 & 260.27 \\
\hline & $\mathbf{M n}_{1}$ & 4.59 & 16.66 & 3.31 & 5.65 & 19.73 & 253.13 \\
\hline & $\mathrm{Mn}_{2}$ & 0.08 & 17.58 & 4.05 & 4.98 & 21.63 & 236.33 \\
\hline \multirow{3}{*}{$\mathbf{K}_{1}$} & $\mathrm{Mn}_{\mathbf{0}}$ & 5.00 & 16.97 & 3.54 & 5.43 & 20.27 & 247.03 \\
\hline & $\mathrm{Mn}_{1}$ & 6.62 & 17.95 & 4.28 & 4.77 & 22.10 & 233.67 \\
\hline & $\mathrm{Mn}_{2}$ & 7.50 & 18.57 & 4.78 & 4.31 & 23.20 & 221.87 \\
\hline \multirow{3}{*}{$\mathrm{K}_{2}$} & $\mathrm{Mn}_{\mathrm{o}}$ & 5.52 & 17.27 & 3.79 & 5.20 & 20.77 & 242.23 \\
\hline & $\mathrm{Mn}_{1}$ & 7.19 & 18.25 & 4.53 & 4.55 & 22.63 & 227.37 \\
\hline & $\mathrm{Mn}_{2}$ & 8.17 & 18.93 & 5.03 & 4.08 & 23.33 & 217.53 \\
\hline \multicolumn{2}{|c|}{ L. S. $D_{0.05}$} & 0.35 & 0.16 & 0.17 & 0.13 & 0.70 & 4.03 \\
\hline
\end{tabular}

*Combined analysis of the two studied seasons

$\mathrm{K}_{\mathrm{o}}=0, \mathrm{~K}_{1}=62.5 \mathrm{Kg} \mathrm{K}_{2} \mathrm{O} \mathrm{fed}^{-1}, \mathrm{~K}_{2}=125 \mathrm{Kg} \mathrm{K}_{2} \mathrm{O} \mathrm{fed}^{-1}, \mathrm{Mn}_{\mathrm{o}}=0, \mathrm{Mn}_{1}=0.3 \mathrm{~g} \mathrm{Mn} \mathrm{L}^{-1}, \mathrm{Mn}_{2}=0.6 \mathrm{~g} \mathrm{Mn} \mathrm{L}^{-1}$. 


\section{REFERENCES}

Al - Jaloud, A. A., A. H. Abdel Gadir, A. H. Errebhi, M. A. Baig, M.S. Al - Asker and H. B. Sarhan (2006). The effect of fertigating different levels of nitrogen, phosphorus and potassium on greenhouse cucumber yield. Acta Hort., 710 : 359 - 363.

Almeida, E. I. B., M. C. de M. Correa, G. N. Nobrega, E. A. R. Pinheiro and F. F. Lima (2012). Crescimento e marcha de absorção de macronutrientes para a cultivar de melancia Crimson Sweet. Revista Agro @ mbiente, 6 : 205 - 214.

Al-Moshileh, A. M., M. A. Errebhi and M. I. Motawei (2005). Effect of various potassium and nitrogen rates and splitting methods on potato under sandy soil and arid environmental conditions. Emirates journal of Agricultural Science, 17 (1) : 1 -9.

Al-Moshileh, A. M., M. A. Errebhi and H. A. Obiadalla - Ali (2017). Effect of potassium fertilization on tomato and cucumber plants under greenhouse conditions. Bioscience Research, 14 (1) : 68 - 74.

Al-Mukhtar, F. A., F. M. Hummadi and F. H. Al - Sahaf (1988). Effect of different levels of NPK fertilizer on growth and yield of two summer squash cultivars. Acta Hort., 220 : 253 - 258.

Al-Sahaf, F. H. (1989). Practical Plant Nutrition. Ministry of higher eduction and scientific research. Baghdad univ. Iraq.

Anderson, J. M and N. A. Pyliotis (1996). Studies with manganese deficient chloroplasts. Biochemistry and Biophysics Acta, 189 : 280 - 293.

Araújo, H. S., B. R. de Quadros, A. I. I. Cardoso and C. V Correa (2012). Doses de potássio em cobertura na cultura da abóbora. Pesquisa Agropecuaria trotpical, (42) : 469 475.

A.O.A.C. (2000). Association of Official Agricultural Chemists, Official and Tentative Methods of Analysis. $11^{\text {th }} \mathrm{ed}$. Washington, D. C., U. S. A.
Burnell, J. N. (1988). The Biochemistry of Manganese in Plants. In Graham R. D, Hannam R, and Uren N. C. (Eds) Manganese in Soils and Plants. Kluwer Academic Publishers, Dordrecht, Netherlands, pp: 125 - 137.

Chapman, D. H. and P. E. pratt (1961). Methods of Analysis for Soil, Plant and Waters. Univ. of Calif., Div. Agric. Science, USA.

Darwesh, D. A. (2011). Effect of soil and foliar application of iron chelat on nutrient balance in lentil (Lens esculenta L.) by using modified dris equation. Mesopotamia J. Agric. Ric, 39 (3).

Fernandes, Carlos N. V., Bentio M. de Azevedo, C. C. Cebora, N. D Chrislene, O. F. Mario and R. B. C. Fellype (2016). Potassium fertilizer applied by different methods in the zucchini crop. RevistaBrasileira de Engenharia Agricola e Ambiental, 20 (7) : 643 648.

Gomez, K. A. and C. M. Gomez (1984). Satistical Procedure for Agricultural Research. J. ohn Wiley and Sons Ine. Newo york.

Grangeiro, L. C. and A. B. Cecilio Filho (2006). Características de produção de frutos de melancia sem sementes em função de fontes e doses de potássio. Horticultura Brasileira, 24 : 451 - 454.

Hebbarb, S. S., B. K. Ramachandrappa, A. H. V. Nanjappaa and M. prabhakarb (2004). Studies on NPK drip fertigation in field grown tomato. European j. Agron., 21 (1) : 117 - 127.

Jacobs, M. B. (1951). The Chemical Analysis Prentice. Hall of India private Limited, New Delhi, pp. 111 - 204.

Kacha, H. L., B. P. Jethaloja, R. S. Chovatiya and JatGiriraj (2017). Growth and yield of watermelon affected by chemical fertilizers. International j. of chemical studies, 5 (4): $1701-1704$.

Klute, A. (1986). Methods of Soil Analysis. $2^{\text {nd }}$ Ed., Part 1 soil sci. Amer., Madison, Wisc. USA. 
Majeed, S. H. and M. J. Mahmoud (1988). Iraq Herbs and plants in popular medical and Scientific research. First publication. Drug and Drug Education department. Biological Res. Centre, Scientific Res. Council, Iraq.

Marie, A.I. and G.H. Mohammed (2010). Effect of foliar application of potassium and IAA on growth and yield of tow cultivars of squash (Cucurbita pepo L.). j.Tikrit Univ. Agric. Eciences .10 (2): 229 -242

Marschner, H. (1995). Mineral Nutrition of Higher Plants. Academic Press : 324332.

Mohamed, Hoda A., Asmaa R. Mahmoud, M. I. Ezzo and Magda M. Hafez (2010). Physiological response of growth, yield and its quality of squash (cucurbita pepo L.) to foliar application of some nutrients. Res. J. Agric. and Biol. Sciences, 6 (4): 568576.

Nogueira, F. P., Silva, M. V. T. da, Oliveira, F. L.de, Chaves, S. W. P. and Medeiros, J. F. de. (2014). Crescimento e marcha de absorção de nutrientes da melancieira fertirrigada com diferentes doses de $\mathrm{N}$ e K. Revista verde de Agroecologia e Desenvolvimento Sustentavel, 9: 35 42.

Novais, R. E., V. H. Venegas, N. F. de Barros, R. L. Fontes, R. B. cantarutti and J. C. L. Neves (2007). Fertilidade do solo. Vicosa : Sociedade Brasileira de Ciencia do Solo, 1017 p. Cited by Fernandes, carlos N. V., Azevedo Bentio M. de, C. C. Cebora, N. D chrislene, O. F. Mario and R. B. C. Fellype (2016) Potassium fertilizer applied by different methods in the zucchini crop. RevistaBrasileira de Engenharia Agricola e Ambiental, 20 (7): 643-648.

Oloyede, F. M., I. O. Obisesan, G. 0 . Agbaje and E. M. Obuotor (2012). Effect of NPK fertilizer on composition of pumpkin (Cucurbilapepo Linn.) seeds. The scientific world j., Article ID 808196, 6 pages.
Orhue, E. R. and C. N. C. Nwaoguala (2010). The effect of manganese on early growth of fluted pumpkin (Telfairia occidentalis Hook F) in an ultisol. J. Tropical Agric., Food, Environ. and Extension, 9 (3): 154 160.

Page, A. L. (1982). Methods of Soil Analysis. $2^{\text {nd }}$ Ed., Part 1, Soil Sci. Soc. Amer., Madison, Wisc., USA.

Patil, R. B. (2011). Role of potassium humate on growth and yield of soybean and black gram. International J. pharma and Bio sciences, 2 (1) : 242 $-246$.

Prajapati, K. and H. A. Modi (2012). The importance of potassium in plant growth - A review. Indian J. plant sci., ISSN : 2319 - 3824.

Sadasivam, S. and A. Manickam (1996). Biochemical Methods, $2^{\text {nd }}$ Ed. New Age international India.

Silva, M. V. T. da, R. M. Lima, S. W. P. Chaves, A. M. A. de Medeiros, N. K. C. Silva and F. L. de Oliveira (2013). Diagnose foliar da abóbora submetida a de salinida diferentes níveis de e doses crescentes de nitrogenio. Agropecuaria Científica no Semiárido, 9 : $118-125$.

Silva Júnior, M. J., J. F. de Mederios, F. H. T. de Oliveira and I. Dutra (2006). Acúmulo de matéria seca e absorção de nutrientes pelo meloeiro "Pele de Sapo". RevistaBrasileira de Engenharia Agricola e Ambiental, 10 : 364-368.

Slinkard, J. and V. L. Singlelon (1977). Total phenol analysis. automation and comparison with manual methods. Am. J. Enol. Viticult, $28: 49-55$.

Taiz, L. and E. Zeiger (2009). Fisiologia Vegetal. 4 ed. Porto alegre : Artmed : 819 p. Cited by Almeida, E. I. B.; M. C. de M. Correa; G. N. Nobrega; E. A. R. Pinheiro; and F. F. Lima. (2012). Crescimento e marcha de absorção de macronutrientes para a cultivar de melancia Crimson Sweet. Revista Agro@ mbiente, 6 : 205 - 214. 
تأثير البوتاسيوم والمنجنيز على إنتاجية وجودة محصول الكوسة

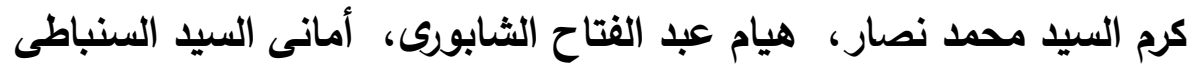
معهة بحوث الأراضي والمياه والبيئة - مركز البحوث الزراعية - الجيزة - مصر المر المياري

الملخص العربي

أجريت تجربتان حقليتان في مزرعة خاصة في مدينة السرو التابعة لمركز الزرقا محافظة دمياط (خط عرض

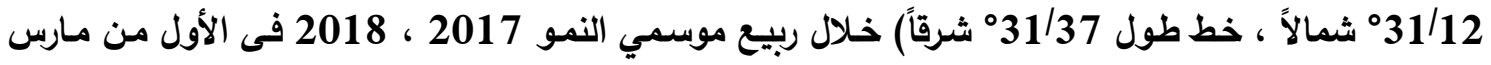

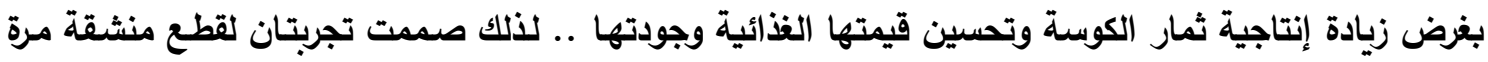
واحدة في ثلاث مكررات حيث شغلت القطع الرئيسية بثلاث معاملات للبوتاسيوم

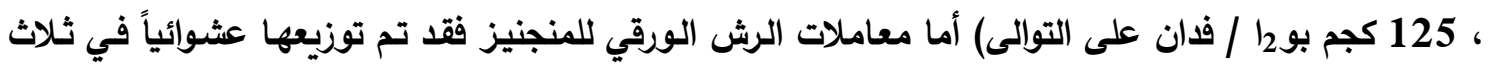
معدلات أشارت النتائج المتحصل عليها إلى النقاط الهامة الآتية :

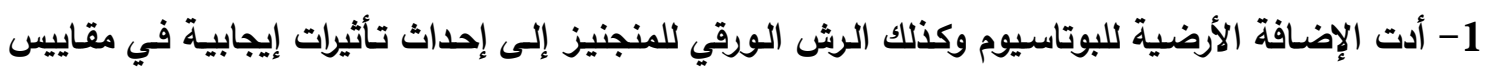

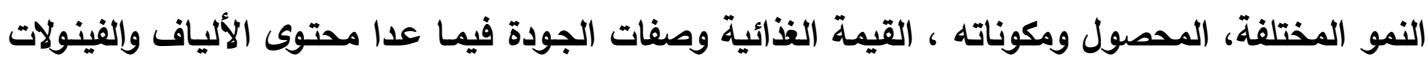

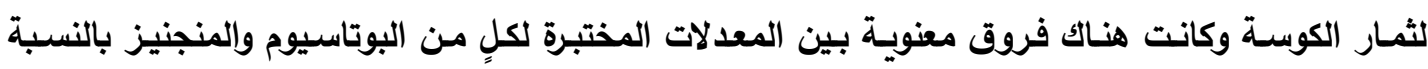

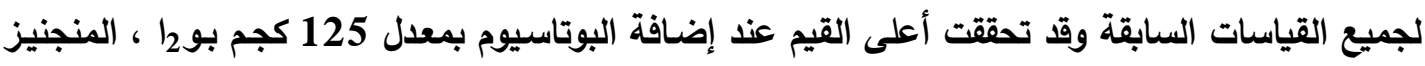

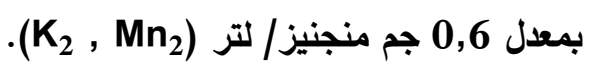

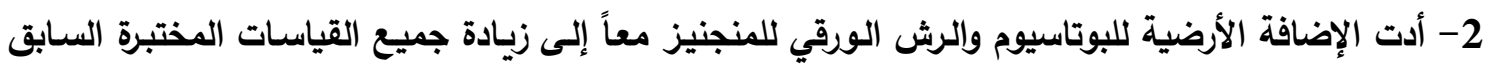

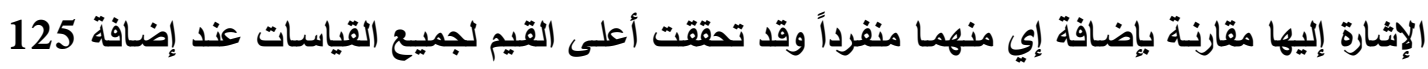

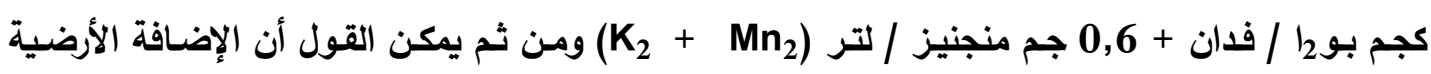

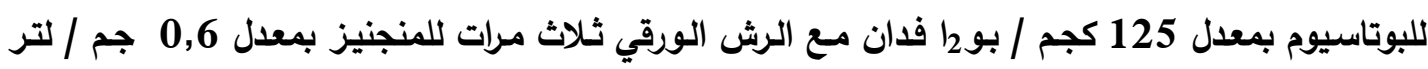

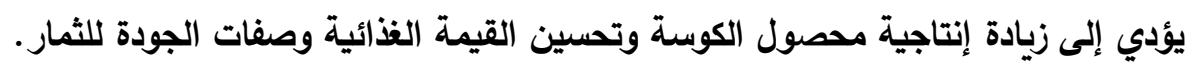

